American Journal of Applied Sciences 6 (6): 1158-1168, 2009

ISSN 1546-9239

(C) 2009 Science Publications

\title{
Media Improvement for Hydrogen Production Using C. acetobutylicum NCIMB 13357
}

\author{
${ }^{1}$ Mohd Sahaid Kalil, ${ }^{2}$ Hisham Salem Saleh Alshiyab and ${ }^{2}$ Wan Mohtar Wan Yusoff \\ ${ }^{1}$ Department of Chemical and Process Engineering, Faculty of Engineering, \\ University Kebangsaan Malaysia, 43600 UKM Bangi Selangor, Malaysia \\ ${ }^{2}$ School of Bioscience and Biotechnology, Faculty of Science and Technology \\ University Kebangsaan Malaysia, 43600 UKM Bangi Selangor, Malaysia
}

\begin{abstract}
Problem statement: Some component of fermentation medium showed to reduce the bacterial production of hydrogen. Approach: Reinforced clostridium medium is a selected medium for Clostridium species. Reformulation this medium regarding hydrogen production may focus on such medium composition that enhance or reduce the bacterial productivity. The optimum $\mathrm{pH}$ and temperature for hydrogen production were at initial $\mathrm{pH}$ of 7.0 and $30^{\circ} \mathrm{C}$. Results: The results show that both nitrogen source and its concentration affected biomass growth as well as $\mathrm{H}_{2}$ yield. Yeast extract at concentration of $13 \mathrm{gL}^{-1}$ was the best organic nitrogen source and resulted in hydrogen yield $\left(\mathrm{Y}_{\mathrm{P} / \mathrm{S}}\right)$ of $308 \mathrm{~mL} \mathrm{~g}^{-1}$ glucose utilized with biomass concentration of $1.1 \mathrm{gL}^{-1}$, hydrogen yield per biomass $\left(\mathrm{Y}_{\mathrm{P} / \mathrm{X}}\right)$ of $280 \mathrm{~mL} \mathrm{~g}^{-1} \mathrm{~L}^{-1}$, biomass per substrate utilized $\left(\mathrm{Y}_{\mathrm{X} / \mathrm{S}}\right)$ of 0.22 and produced hydrogen in gram per gram of glucose utilized $\left(\mathrm{Y}_{\mathrm{H} / \mathrm{S} / \mathrm{s}}\right)$ of 0.0275 . $\mathrm{C} / \mathrm{N}$ of 70 enhanced the $\mathrm{Y}_{\mathrm{P} / \mathrm{S}}$ from $308 \mathrm{~mL} \mathrm{~g}^{-1}$ to $350 \mathrm{~mL}$ $\mathrm{g}^{-1}$ glucose utilized with biomass concentration of $1.22 \mathrm{gL}^{-1}, \mathrm{Y}_{\mathrm{P} / \mathrm{X}}$ of $287 \mathrm{~mL} \mathrm{~g}^{-1} \mathrm{~L}^{-1}, \mathrm{Y}_{\mathrm{X} / \mathrm{S}}$ of 0.244 and $\left(\mathrm{Y}_{\mathrm{H} 2 / \mathrm{S}}\right)$ of 0.03125 . In the absence of sodium chloride and sodium acetate further enhanced $\mathrm{Y}_{\mathrm{P} / \mathrm{s}}$ from $350 \mathrm{~mL} \mathrm{~g}^{-1}$ glucose utilized to $391 \mathrm{~mL} \mathrm{~g}^{-1}$ glucose utilized with maximum hydrogen productivity of $77.5 \mathrm{~mL} \mathrm{~L}^{-1} \mathrm{~h}^{-1}$, whereas RCM medium gave the highest hydrogen productivity of $63.5 \mathrm{~mL} \mathrm{~L}^{-1} \mathrm{~h}^{-1}$. Results also show that Sodium Chloride and Sodium Acetate in the medium adversely affect growth. Removal of both components from the medium enhanced the biomass concentration from 1.22$1.34 \mathrm{gL}^{-1}, \mathrm{Y}_{\mathrm{P} / \mathrm{X}}$ of $254 \mathrm{~mL} \mathrm{~g}^{-1} \mathrm{~L}^{-1}, \mathrm{Y}_{\mathrm{X} / \mathrm{S}}$ of 0.268 and $\left(\mathrm{Y}_{\mathrm{H} 2 / \mathrm{S}}\right)$ of 0.0349 . Conclusion: The medium an improved containing (glucose $5 \mathrm{gL}^{-1}$, Yeast extract $\mathrm{gL}^{-1}$, L-Cystine. $\mathrm{HCl} 1 \mathrm{gL}^{-1}$ and Bacteriological agar $0.5 \mathrm{gL}^{-1}$ ), was able to enhance the hydrogen productivity.
\end{abstract}

Key words: Medium formulation, biohydrogen, C.acetobutylicum NCIMB13357, salts

\section{INTRODUCTION}

Fossil fuel, the major global energy resource, causes global atmospheric pollution problems during combustion. An alternative to fossil fuel is biohydrogen, which is an ideal, clean and sustainable energy source for the future because of its high conversion and nonpolluting nature. At present, hydrogen is produced mainly from fossil fuels, but biohydrogen can be produced from biomass Biohydrogen production processes, including fermentation, are more environmentally friendly and less energy intensive compared to thermo-chemical and electrochemical processes in hydrogen production ${ }^{[1]}$.

Medium formulation is an essential stage in the design of successful laboratory experiments. The constituents of a medium must satisfy the elemental requirements for cell biomass and metabolites production and there must be an adequate supply of energy for biosynthesis and cell maintenance. The first step to consider is an equation based on the stoichiometry for growth and product formation ${ }^{[2]} \mathrm{A}$ fermentation process consists of a number of operations and stages for which a whole family of inter-related media must be developed. Before attempting any media one must make the objective of the specific stage of the process absolutely clear. There is no requirement for final product formation therefore the medium may be designed purely to satisfy the growth requirement of the organism. In order to obtain rapid growth in seed and final stages, the medium must contain sources of energy, carbon, nitrogen and phosphate, trace metal and any specific growth factors which the organism itself cannot manufacture. A single carbohydrate material

Corresponding Author: Hisham Salem Alshiyab, Department of Chemical and Process Engineering, Faculty of Engineering, University Kebangsaan Malaysia, 43600 UKM Bangi Selangor, Malaysia 
may act as both carbon and energy source although a second material, may be required and the carbon skeletons of nitrogenous organic compounds may contribute to both requirements. As much as $15 \%$ of the biomass dry weight may be composed of nitrogen, therefore the medium must provide at least this amount of a suitable material. Although many industrial organisms utilize inorganic nitrogen, growth and productivity is invariable stimulated by the addition of suitable organic nitrogenous materials ${ }^{[2]}$.

The Carbon to Nitrogen $(\mathrm{C} / \mathrm{N})$ ratio is important in a biological process. Mixed microfloras from sewage or compost are usually used in biological hydrogen production from organic wastes ${ }^{[3]}$. Microflora requires a proper nitrogen supplement for metabolism during fermentation. A proper $\mathrm{C} / \mathrm{N}$-ratio value for pure culture is necessary to optimize anaerobic hydrogen production from organic substrate. It is necessary to maintain proper composition of the feedstock for efficient plant operation so that the $\mathrm{C}: \mathrm{N}$ ratio in feed remains within desired range. It is generally found that during anaerobic digestion microorganisms utilize carbon 2530 times faster than nitrogen. Thus to meet this requirement, microbes need a 20-30:1 ratio of $\mathrm{C}$ to $\mathrm{N}$ with the largest percentage of the carbon being readily degradable $^{[4]}$. Waste material that is low in $\mathrm{C}$ can be combined with materials high in $\mathrm{N}$ to attain desired $\mathrm{C}: \mathrm{N}$ ratio of $30: 1$. Some studies also suggested that $\mathrm{C}$ : $\mathrm{N}$ ratio varies with temperature ${ }^{[4]}$.

Previous investigations on sodium inhibition were mainly concentrated on undomesticated methanogenic bacteria in anaerobic digestion process and under different conditions, different bacteria (microbes) have different tolerances to sodium toxicity. However, few works have been done on the effect of sodium salt on hydrogen-producing bacteria (pure bacteria). However, ionic strength is one of the important factors influencing $\mathrm{H}_{2}$ production because the growth of fermentative bacteria requires a number of ions such as sodium and potassium. The ionic strength in the solution is determined by both ion species and its concentrations and it can be either stimulatory or inhibitory and even toxic to $\mathrm{H}_{2}$ production. A low level of ionic strength may have no or even stimulatory effect on $\mathrm{H}_{2}$ production. However, a high level of ionic strength can result in cell lyses ${ }^{[5]}$. Therefore, a proper ionic strength is necessary to optimize anaerobic hydrogen production process.

Inhibitory effect of ionic strength on $\mathrm{H}_{2}$ fermentation is available in the literature. Therefore this study was conducted to investigate the influence of ionic strength on glucose degradation, $\mathrm{H}_{2}$ production. The ionic strength in the solution was provided in the form of Sodium Chloride and Sodium Acetate. For above reasons, RCM have all these restrictions for maximum production of hydrogen so this study was aimed to reformulate RCM medium for hydrogen production using anaerobic bacterium C.acetobutylicum NCIMB13357.

\section{MATERIALS AND METHODS}

Microorganism and culture conditions: C. acetobutylicum NCIMB 13357 was purchased from a British culture collection, NCIMB Ltd. Scotland, UK. The bacterium was cultivated in anaerobic condition in Reinforced Clostridial Medium (RCM) for $24 \mathrm{~h}$ at $30^{\circ} \mathrm{C}$. Liquid medium of RCM was used for inoculums preparation. Measuring an optical density at $600 \mathrm{~nm}$ using a spectrophotometer monitored the growth of culture in RCM. Only inoculum with Optical Density (OD) values greater than 0.4-0.6 after $18 \mathrm{~h}$ cultivation was used as inoculums. An inoculum of $10 \% \mathrm{v} / \mathrm{v}$ was used throughout this study.

Cultivation medium: The medium we started to study has the following composition in $\left(\mathrm{gL}^{-1}\right)$ : Glucose (5), one of the following organic nitrogen source (Yeast Extract/Trypton/Peptone) (13), Sodium chloride (5), Sodium acetate (3), L-Cystine. $\mathrm{HCl}$ (1.0), Agar (0.5).

The initial anaerobic condition in the reactor after inoculation inside the anaerobic glove box was established by replacing the gaseous phase with nitrogen at start of cultivation. Then incubated at $30^{\circ} \mathrm{C}$ in temperature controlled water bath without shaking. The evolved gas was monitored and collected in a gas collection cylinder and the volume of evolved gas was measured at room temperature by the water displacement method $^{[6]}$ in a graduated cylinder (inverted), that had been filled with water of $\mathrm{pH} 3$ or less in order to prevent dissolution of the gas components.

Analytical methods: The gas composition was determined by gas chromatography (Shimadzu Co., Kyoto, GC-8A) under the following conditions: Column: Porapack-Q, carrier gas: Nitrogen, flow rate: $33 \mathrm{~mL} \mathrm{~min}^{-1}$; column temperature: $50^{\circ} \mathrm{C}$, injection temperature: $100^{\circ} \mathrm{C}$, detector temperature: $50^{\circ} \mathrm{C}$, detector: Thermal Conductivity Detector (TCD). The soluble glucose concentration was measured at the end of each batch experiment for the calculation of the amount of glucose consumed by DNS method modified by Miller ${ }^{[7]}$ using spectrophotometer (UV 1601 IPC, Shimadzu corporation- Japan) optical density (OD $550 \mathrm{~nm}$ ). Individual batch experiments were observed until the hydrogen production from each bottle stopped. 
Final medium $\mathrm{pH}$ was measured by $\mathrm{pH}$ meter (MettlerTeldo) and Final biomass was measured by Spectrophotometer (UV 1601 IPC, Shimadzu corporation- Japan) at optical density (OD $600 \mathrm{~nm})$. All of these data were the average (mean) of three trials.

Experimental design: To study the effect of nitrogen source, we started add $13 \mathrm{gL}^{-1}$ of one of the following organic nitrogen Yeast Extract, Trypton and Peptone, to fermentation medium and for comparison we used different source of inorganic nitrogen and its effect on hydrogen production by $C$. acetobutylicum NCIMB 13357. For $\mathrm{C} / \mathrm{N}$ ratio determination, we determined the nitrogen content of proper nitrogen source using Kjeldahl method ${ }^{[8]}$. The Kjeldahl method is the standard method of nitrogen determination. The method consists of three basic steps: (1) Digestion of the sample in sulfuric acid with a catalyst, which results in conversion of nitrogen to ammonia; (2) Distillation of the ammonia into a trapping solution and (3) Quantification of the ammonia by titration with a standard solution. Finally, to study the effect of the two major components of RCM medium which are Sodium Chloride and Sodium Acetate, on hydrogen production by C.acetobutylicum NCIMB13357.

The optimization experiments were designed to reformulate RCM medium for hydrogen production. This method considers only the important combined effects of nutrient in the experimental plan. These combined effects can be easily determined after a series of pre-experiments. The optimization criteria were the maximum hydrogen productivity (the ability to convert glucose into hydrogen) and hydrogen production yield values (the volume of hydrogen production per utilized glucose). A confirmation experiment was conducted using the selected concentration obtained based on the Hydrogen yield values.

\section{RESULTS AND DISCUSSION}

Effect of organic nitrogen source on hydrogen production: The results shown in Table 1 indicated that using RCM medium for hydrogen production by C.acetobutylicum NCIMB13357, gave maximum of $1400 \mathrm{~mL} \mathrm{~L}^{-1}$ and that was for $5 \mathrm{gL}^{-1}$ glucose and $1 \mathrm{gL}^{-1}$ soluble starch with maximum $\mathrm{H}_{2}$ productivity of $63.5 \mathrm{~mL} \mathrm{~L}^{-1} \mathrm{~h}^{-1}$. Compared with the results of the new medium, the results shown in Fig. 1a indicated that Hydrogen yield obtained using $5 \mathrm{gL}^{-1}$ of glucose and $13 \mathrm{gL}^{-1}$ of Yeast extract gave maximum of $308 \mathrm{~mL} \mathrm{~g}^{-1}$ glucose utilized with maximum productivity by $55 \mathrm{~mL} \mathrm{~L}^{-1} \mathrm{~h}^{-1}$, indicated that nitrogen source had remarkable effect on hydrogen production and that depend on the sources we used.
Table 1: Results of using RCM medium for $\mathrm{H}_{2}$ production by C.acetobutylicum NCIMB13357. $\mathrm{Y}_{\mathrm{P} / \mathrm{S}}\left(\mathrm{mL} \mathrm{g}^{-1}\right)$, Productivity $\left(\mathrm{mL} \mathrm{L}^{-1} \mathrm{~h}^{-1}\right)$. [Biomass] $\left(\mathrm{gL}^{-1}\right)$

\begin{tabular}{|c|c|c|c|}
\hline & $\mathrm{H}_{2} \mathrm{P}$ & $\mathrm{Y}_{\mathrm{P} / \mathrm{S}}$ & [Biomass] \\
\hline RCM & 63.5 & 1400 & 1.22 \\
\hline
\end{tabular}

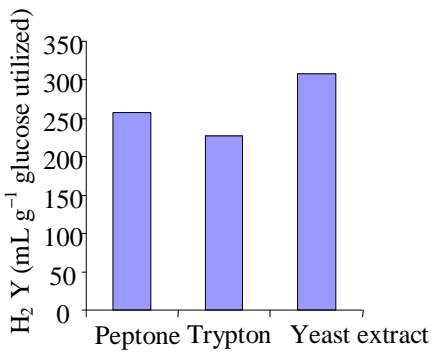

(a)

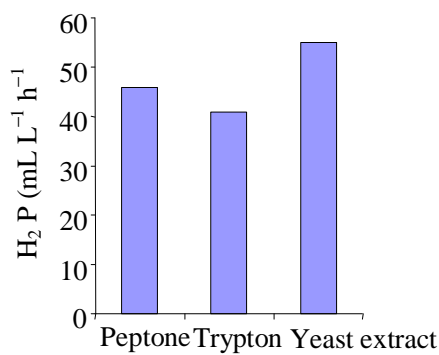

(b)

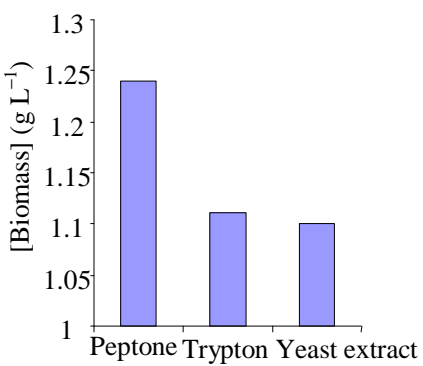

(c)

Fig. 1: Effect of organic nitrogen source $\left(13 \mathrm{gL}^{-1}\right.$ each) on (a): $\mathrm{H}_{2}$ yield $\left(\mathrm{mL} \mathrm{g}^{-1}\right)$ (Utilized); (b): $\mathrm{H}_{2} \mathrm{P}$ $\left(\mathrm{mL} \mathrm{L}^{-1} \mathrm{~h}^{-1}\right)$ and (c): Biomass concentration $\left(\mathrm{gL}^{-1}\right)$. [Glucose]. $5 \mathrm{gL}^{-1}$, inoculum size $10 \%$ (v/v), I pH. 7.0, Temperature $30^{\circ} \mathrm{C}$

The results shown in Fig. 1a shown that the highest $\mathrm{H}_{2}$ yield (308, 258 and $228 \mathrm{~mL} \mathrm{~g}^{-1}$ glucose utilized) was obtained by using $13 \mathrm{gL}^{-1}$ of Yeast Extract, Peptone and Trypton respectively. The highest hydrogen yield of $308 \mathrm{~mL} \mathrm{~g}^{-1}$ glucose utilized was obtained using $13 \mathrm{gL}^{-1}$ yeast extract with maximum biomass concentration of $1.1 \mathrm{gL}^{-1}$.

The results shown in Fig. 1a indicating that cultures supplemented with yeast extract, peptone and tryptone produced higher $\mathrm{H}_{2}$ yields among these sources, yeast extract was the best source of nitrogen for $\mathrm{H}_{2}$ production and these results agreed with the 
finding of Lay ${ }^{[9]}$ they found that the cultures supplemented with yeast extract, tryptone and peptone produced higher $\mathrm{H}_{2}$ yields with near complete sugar consumption (98.9-99.9\%) Among these sources, they found that yeast extract was the best source of nitrogen for $\mathrm{H}_{2}$ production because it facilitated the highest production rate. However, they reported that cultivation with other organic nitrogen sources such as beef extract, cotton seed flour, corn gluten meal or soybean meal was characterized by incomplete sugar consumption, lower final culture $\mathrm{pHs}$ and lower $\mathrm{H}_{2}$ production than the control. The results of present study was also agreed with Mongi et al. ${ }^{[10]}$, they found the yeast extract using $0.1 \%$ was the best nitrogen source for hydrogen production and also with Morimoto ${ }^{[6]}$, they reported that by using $0.2 \%$ of yeast extract, the hydrogen yield was the best among the nitrogen source they used.

The results shown in Fig. $1 \mathrm{~b}$ and $\mathrm{c}$ showed that bacterial productivity of hydrogen was increased depending on the nitrogen source used and reached the maximum by using Yeast extract of $55 \mathrm{~mL} \mathrm{~L}^{-1} \mathrm{~h}^{-1}$ with the lowest biomass concentration of $1.1 \mathrm{gL}^{-1}$ compared with other organic nitrogen source, suggested that yeast extract enhanced hydrogen production than other organic sources.

Effect on nitrogen source on hydrogen production: For comparison, we tried to find out the effect of using inorganic source (all with same concentration $\left(13 \mathrm{gL}^{-1}\right)$. The results illustrated that organic nitrogen was better than inorganic source for hydrogen production with maximum hydrogen yield of $308 \mathrm{mLg}^{-1}$ glucose utilized with that also the results shown in Fig. 2c showed that organic nitrogen was better for bacterial growth than inorganic source. In general, $\mathrm{H}_{2}$ production by cultures supplemented with organic nitrogen was higher than those supplemented with inorganic nitrogen sources.

Replacing organic with inorganic resulted in poor $\mathrm{H}_{2}$ production and bacterial growth. The results shown in Fig. 2a, were fully agreed with a number of investigators that they have used inorganic nitrogen sources such as ammonium hydrogen carbonate $(9,11-$ 13) and ammonium chloride (14-15) in $\mathrm{H}_{2}$ fermentation media, their results indicated that the lower yield they obtained it might be due to the nitrogen source and the microorganism(s) they were used, others have shown that when ammonium chloride replaced peptone as a nitrogen source, $\mathrm{H}_{2}$ yields are halved ${ }^{[16]}$. These observations were attributed their lower hydrogen yield to the composition of the nitrogen source in fermentation medium they used. The results shown in Fig. $2 b$ indicated that bacterial productivity of hydrogen was depend on the nitrogen source in fermentation medium since all nitrogen source were used have the same concentration $13 \mathrm{gL}^{-1}$.

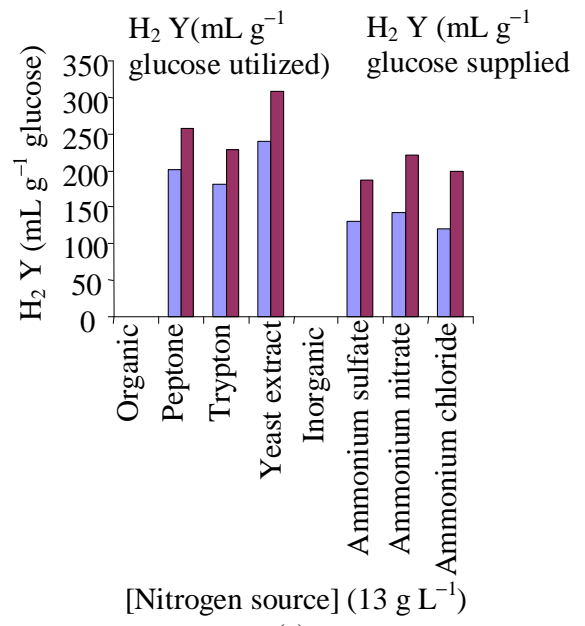

(a)

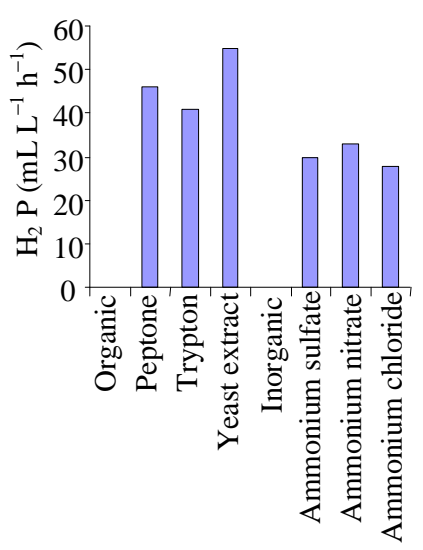

(b)

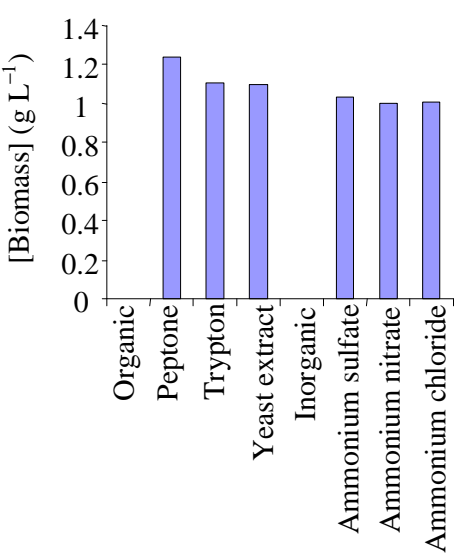

(c)

Fig. 2: Effect of nitrogen source ( $13 \mathrm{~g}^{-1}$ each) on (a): $\mathrm{H}_{2}$ yield $\left(\mathrm{mLg}^{-1}\right)$ (Utilized); (b): $\mathrm{H}_{2} \mathrm{P}\left(\mathrm{mL} \mathrm{L}^{-1} \mathrm{~h}^{-1}\right)$ and (c): Biomass concentration $\left(\mathrm{gL}^{-1}\right)$. [Glucose]. $5 \mathrm{gL}^{-1}$, inoculum size $10 \%(\mathrm{v} / \mathrm{v})$, I pH. 7.0, Temperature $30^{\circ} \mathrm{C}$ 
Organic nitrogen is a complex nitrogen source composed of a spectrum of peptides and free amino acids. During fermentation, these are taken up from the medium by the cell and directly incorporated into proteins or transformed into other cellular nitrogenous constituents $^{[17]}$. By contrast, the cell spends more energy and time in synthesizing amino acids for protein synthesis from inorganic nitrogen sources ${ }^{[18]}$. Among organic nitrogen sources, differences in protein and amino acid composition could have accounted for the differences in the production rates and yields observed. Yeast Extract comprises the water soluble components of the yeast cell, the composition of which is primarily amino acids, peptides, carbohydrates and salts. Furthermore Yeast Extracts are rich in nitrogen, vitamins and other growth stimulating compounds and therefore used as an ingredient in media for the cultivation of microorganisms.

Effect of medium $\mathrm{C} / \mathrm{N}$ ratio on hydrogen production: It was reported that $\mathrm{C} / \mathrm{N}$ ratio in fermentation medium may have effect on the bacterium metabolites and may share with other factor to make the bacterium shift on its metabolism. The following experiments were conducted to find out the effect of nitrogen concentration and the proper $\mathrm{C} / \mathrm{N}$ ratio that gave the maximum production of hydrogen.

The results shown in Fig. 3 showed that nitrogen concentration (measured according to Kjeldahl method $^{[8]}$, have affected on the quantity of hydrogen production from $308-350 \mathrm{~mL} \mathrm{~g}^{-1}$ glucose utilized. and showed that by using different $\mathrm{C} / \mathrm{N}$ ratio of glucose and yeast extract, the highest hydrogen yield was at $\mathrm{C} / \mathrm{N}$ ratio of 70 . Following the Kjeldahl method ${ }^{[8]}$, nitrogen concentration yeast extract have only $14 \mathrm{mgg}^{-1} \mathrm{~N} 2$. The results shown in Fig. 3, demonstrated that the nitrogen concentration affect in both ways (increasing or decreasing) on hydrogen production. Increasing or decreasing of $\mathrm{C} / \mathrm{N}$ ratio also shows to affect on hydrogen productivity as shown in Fig. $3 \mathrm{~b}$ which enhanced from $49-70 \mathrm{~mL} \mathrm{~L}^{-1} \mathrm{~h}^{-1}$, then decreased for further increasing of $\mathrm{C} / \mathrm{N}$ ratio and this scenario was also for bacterial growth as shown in Fig. 3 and that was clear from the results of biomass concentration in Fig. 3c which illustrated that whole enhancement of hydrogen yield and bacterial productivity was due to the enhancement of bacterial growth at the proper nitrogen concentration.

The carbon to nitrogen $(\mathrm{C} / \mathrm{N})$ ratio is important in a biological process. For example, the $\mathrm{C} / \mathrm{N}$ ratio has been shown to affect fermentative hydrogen by mixed microflora fed with sucrose with an optimal ratio of $47^{[18]}$. Similarly, a study where sucrose was varied at a

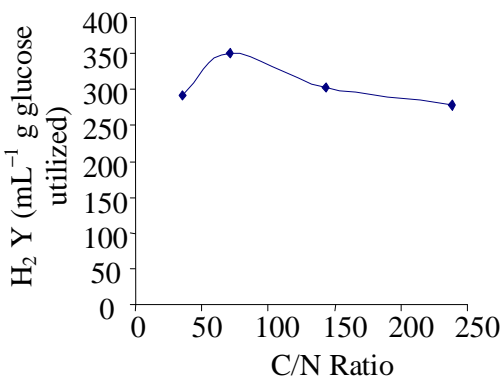

(a)

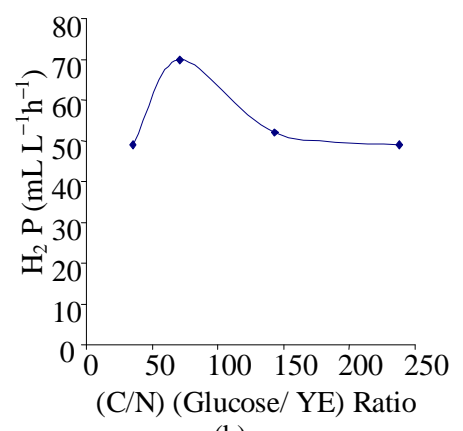

(b)

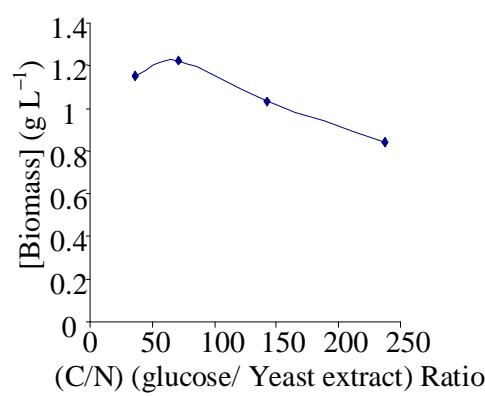

(c)

Fig. 3: Effect of (Glucose/ Yeast Extract) Ratio on (a): $\mathrm{H}_{2}$ yield $\left(\mathrm{mLg}^{-1}\right)$ (Utilized); (b): $\mathrm{H}_{2} \mathrm{P}$ $\left(\mathrm{mL} \mathrm{L}^{-1} \mathrm{~h}^{-1}\right.$ ) and (c): Biomass concentration $\left(\mathrm{gL}^{-1}\right)$ : [Glucose]. $5 \mathrm{gL}^{-1}$, inoculum size $10 \%$ (v/v), I pH. 7.0, Temperature $30^{\circ} \mathrm{C}$

constant ammonium concentration showed that conversion to hydrogen was more efficient at lower substrate loadings ${ }^{[19]}$. Another study was conducted by Bisaillon et al.$^{[20]}$ to investigate some limiting factors in microbial hydrogen fermentation by different strains of E. coli. They found that limitation of phosphate or sulfate was without great effect. However, strains showed the highest yield of hydrogen per glucose when cultured at limiting concentrations of either ammonia or glucose. They reasoned the enhancement of production to $\mathrm{C} / \mathrm{N}$ ratio on culture medium. 
Microflora requires a proper nitrogen supplement for metabolism during fermentation. The results shown in Fig. 3a suggested that at $\mathrm{C} / \mathrm{N}$ ratio of 70 gave the highest hydrogen yield of $350 \mathrm{~mL} \mathrm{~g}^{-1}$ glucose utilized, using $5 \mathrm{gL}^{-1}$ yeast extract was agreed with the finding of Tanisho et $a l^{[21]}$ they reported that Enterobacter aerogenes st.E.82005 yielded 0.5 mole

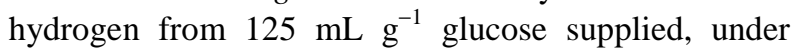
glucose-peptone culture but when they change the peptone from $5-10 \mathrm{gL}^{-1}$, the yield was enhanced to $145 \mathrm{~mL} \mathrm{~g}^{-1}$ glucose supplied, they reasoned that for the substrate they used (Molasses) it might not contain sufficient nitrogen source for bacterial growth. Suggested that proper $\mathrm{C} / \mathrm{N}$ ratio enhance the bacteria for more growth and substrate utilization, also with Aiyer $^{[22]}$ he was study the effect of $\mathrm{C} / \mathrm{N}$ ratio on Bacillus licheniformis SPT 27 to produce alpha amylase. He found that peptone and ammonium hydrogen phosphate as nitrogen source were the best among all organic and inorganic source they used. The optimum $\mathrm{C} / \mathrm{N}$ ratio of $1: 1$ was the sufficient to maximize the bacterial productivity of alpha amylase. Whereas Gottschalk and Morris ${ }^{[23]}$ they used ammonium limited chemostat cultures for solvent production, they stated that they failed to obtain significant levels of solvents, they reasoned that to the ammonia/glucose ratio of the fermentation medium. They claimed that $\mathrm{C} / \mathrm{N}$ ratio of the medium couldn't induce the bacterium they used for solvent production. All of these finding suggested that proper $\mathrm{C} / \mathrm{N}$ ratio should be used to get the maximum production of such product.

Our results agreed with Morimoto et al. ${ }^{[6]}$, they reported that by increasing the yeast extract from 0.2$0.4 \%$, the hydrogen yield of $263 \mathrm{~mL} \mathrm{~g}^{-1}$ glucose supplied), was increased by $30 \%$, but with further increase to $0.8 \%$, the hydrogen yield was decreased by $50 \%$. They reasoned that to the nitrogen concentration in fermentation medium, since they used POME as substrate with mixed culture under thermophilic condition. Whereas Yokoi et al. ${ }^{[24]}$, they reported that, hydrogen was not produced by C.butyricum when they cultivate without nitrogen source, but with organic nitrogen not from inorganic, with $1 \%$ of polypepton, the hydrogen was produced and the amount of hydrogen was maximized to $300 \mathrm{~mL} \mathrm{~g}^{-1}$ glucose supplied, when the reduce the polypeptone to $0.1 \%$, suggested that the addition of this concentration was necessary for hydrogen production by C. butyricum.

$\mathrm{C} / \mathrm{N}$ ratio of this study was higher than that obtained by Lin and lay ${ }^{[18]}$ they were study the effect of $\mathrm{C} / \mathrm{N}$ ratio on biological hydrogen production from sucrose. Their results indicated that the hydrogen production ability of the anaerobic microflora (dominated by Clostridium pasteurianum) in the sewage sludge was dependent on the influent $\mathrm{C} / \mathrm{N}$-ratio. They found at a $\mathrm{C} / \mathrm{N}$-ratio of 47 , the hydrogen yield and hydrogen production rate reached $600 \mathrm{~mL} \mathrm{~g}^{-1}$ of supplied sucrose. They attributed this increased by $500 \%$, compared with the blank to proper $\mathrm{C} / \mathrm{N}$-ratio and that lead to enhancement of hydrogen production. But for the bacterium we used in this study we found that at optimum $\mathrm{C} / \mathrm{N}$ ratio of 70 , hydrogen yield was the maximum and reached to $350 \mathrm{~mL} \mathrm{~g}^{-1}$ glucose utilized (280 $\mathrm{mL} \mathrm{g}^{-1}$ glucose supplied) with maximum increase in the yield $240-280 \mathrm{~mL} \mathrm{~g}^{-1}$ glucose supplied of $17 \%$. Hydrogen productivity was enhanced by using proper nitrogen source with proper $\mathrm{C} / \mathrm{N}$ ratio from $55 \mathrm{~mL} \mathrm{~L}^{-1} \mathrm{~h}^{-1}$ using $13 \mathrm{gL}^{-1}$ of yeast extract to maximum of $70 \mathrm{~mL} \mathrm{~L} \mathrm{~L}^{-1} \mathrm{~h}^{-1}$ using $5 \mathrm{gL}^{-1}$.of yeast extract. For biomass concentration was increased from $1.1 \mathrm{gL}^{-1}$ using $13 \mathrm{gL}^{-1}$ of yeast extract to maximum of $1.22 \mathrm{gL}^{-1}$ using $5 \mathrm{gL}^{-1}$ of yeast extract suggested that proper $\mathrm{C} / \mathrm{N}$ ratio enhanced the bacterial growth The results of this study indicated that by using Yeast extract as nitrogen source and with $\mathrm{C} / \mathrm{N}$ ratio of 70 , hydrogen yield by C.acetobutylicum NCIMB13357 was enhanced, however increasing or decreasing of this ratio would adversely affect on both hydrogen production and bacterial growth.

Effect of sodium chloride and sodium acetate on hydrogen production: It was reported that addition of high $\mathrm{NaCl}$ concentration to the fermentation media has a negative effect on the bacterial growth and then on its metabolites like hydrogen production. Zheng et al. ${ }^{[26]}$. The results shown in Fig. 4a-c indicated that highest yield and both productivity and biomass concentration were at $0.0 \mathrm{gL}^{-1}$ of $\mathrm{NaCl}$. Whereas the results shown in Fig. 5a-c indicated that highest hydrogen yield, hydrogen productivity and biomass concentration were at $0.0 \mathrm{gL}^{-1}$ of $\mathrm{NaCH}_{3} \mathrm{COO}^{-}$).

The present results shown in Fig. $4 \mathrm{a}$ and $5 \mathrm{a}$ illustrated that the maximum $\mathrm{H}_{2}$ yield obtained at 0.0 concentration of $\mathrm{NaCl}$ was $391 \mathrm{Ml} \mathrm{g}^{-1}$ and for Sodium Acetate was $355 \mathrm{~mL} \mathrm{~g}^{-1}$ glucose utilized. The glucose consumption was influenced by the presence of $\mathrm{NaCl}$ and $\mathrm{NaCH}_{3} \mathrm{COO}^{-}$. The results shown in Fig. $4 \mathrm{~d}$ for $\mathrm{NaCl}$ and $5 \mathrm{~d}$ for $\mathrm{NaCH}_{3} \mathrm{COO}^{-}$indicated that with increase in $\mathrm{NaCl}$ from $0.0-5000 \mathrm{mg} \mathrm{L}^{-1}$ and $\mathrm{NaCH}_{3} \mathrm{COO}^{-}$from 0.0$3000 \mathrm{mgL}^{-1}$, the glucose consumption decreased gradually. Compared with the control, at $0.0 \mathrm{mgL}^{-1}$ of $\mathrm{NaCl}$ and $\mathrm{NaCH}_{3} \mathrm{COO}^{-}$, the glucose consumption was enhanced and reached to 87 and $90 \%$ respectively, 
Am. J. Applied Sci., 6 (6): 1158-1168, 2009

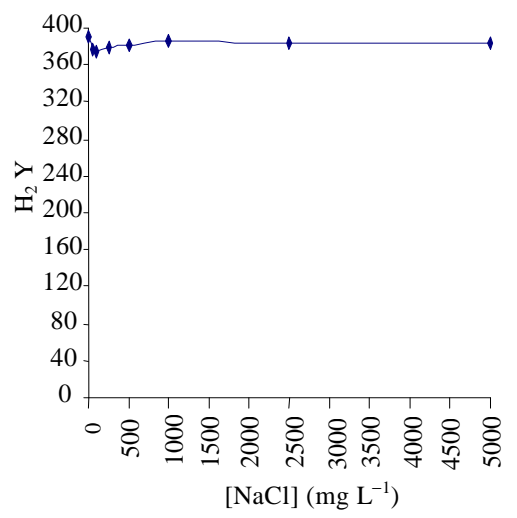

(a)

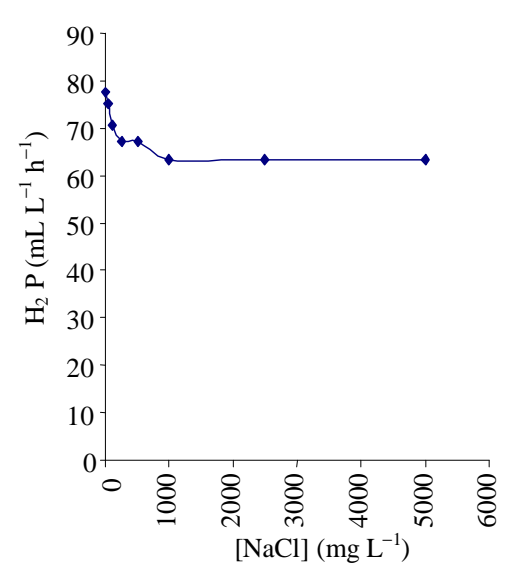

(c)

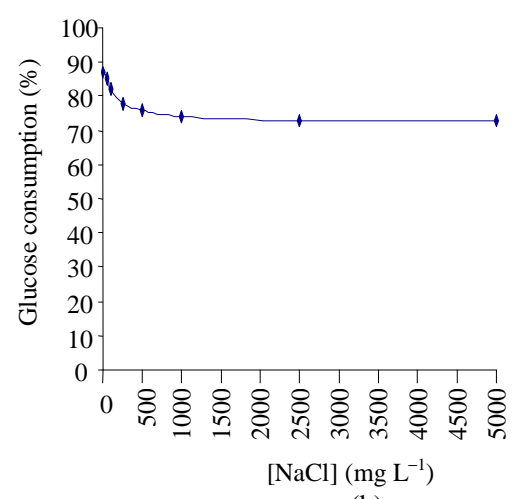

(b)

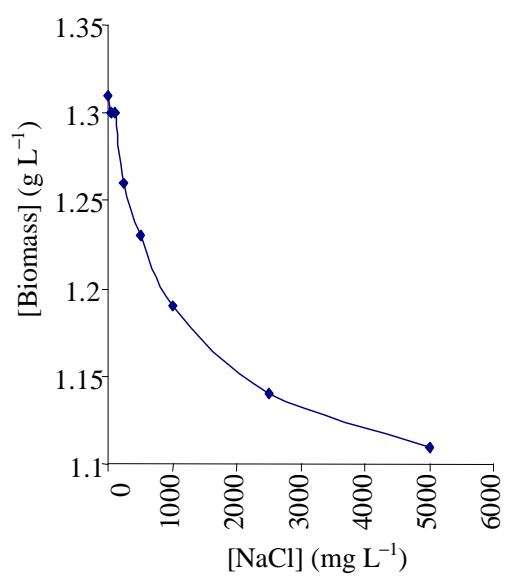

(d)

Fig. 4: Effect of $[\mathrm{NaCl}]$ on (a): $\mathrm{H}_{2}$ yield $\left(\mathrm{mL} \mathrm{g}^{-1}\right.$ glucose utilized), (b): $\mathrm{H}_{2} \mathrm{P}$ (Productivity (mlL $\left.{ }^{-1} \mathrm{~h}^{-1}\right),(\mathrm{c})$ : [Biomass] $\left(\mathrm{gL}^{-1}\right)$ and $(\mathrm{d})$ : Glucose consumption (\%). [Glucose]: $5 \mathrm{gL}^{-1}$, inoculum size 10\% (v/v) I pH. 7.0. Temperature $30^{\circ} \mathrm{C}$

but in the presence of a low level of $\mathrm{NaCl}$ or $\mathrm{NaCl}$, glucose consumption was decreased as the concentration of each was increased. This demonstrates that glucose consumption by C.acetobutylicum NCIMB13357 was influenced by the presence of any amount of $\mathrm{NaCl}$ or $\mathrm{NaCH}_{3} \mathrm{COO}^{-}$in the fermentation medium and that might be the inhibitory effect of sodium at any concentration. The results illustrated that, $\mathrm{NaCl}$ and $\mathrm{NaCH}_{3} \mathrm{COO}^{-}$affect in negative way on glucose degradation.

The results shown in Fig. $4 \mathrm{~b}$ and $5 \mathrm{~b}$, indicated that Hydrogen productivity for $\mathrm{NaCl}$ was dropped from $77.5 \mathrm{~mL} \mathrm{~L}^{-1} \mathrm{~h}^{-1}$ at $0.0 \mathrm{gL}^{-1}-63.5 \mathrm{mlL}^{-1} \mathrm{~h}^{-1}$ at $5 \mathrm{gL}^{-1}$ and for Sodium Acetate from $72.5 \mathrm{mlL}^{-1} \mathrm{~h}^{-1}$ at $0.0 \mathrm{gL}^{-1}$ to $66.5 \mathrm{mlL}^{-1} \mathrm{~h}^{-1}$ at $3 \mathrm{gL}^{-1}$. The maximum productivity of $77.5 \mathrm{mlL}^{-1} \mathrm{~h}^{-1}$ obtained was lower than $137 \mathrm{mlL}^{-1} \mathrm{~h}^{-1}$ which reported by Morimoto et al..$^{[6]}$ at $50^{\circ} \mathrm{C}$ using POME sludge and that due to the carbon sources and bacterial community in sludge. Obtained data demonstrated that hydrogen production was depend on the presence of $\mathrm{NaCl}$ and its concentration and as $\mathrm{NaCl}$ concentration increased the produced hydrogen was decreased. Niel et al. ${ }^{[5]}$ reasoned that inhibition of decreased hydrogen production to increase in concentration of the $\mathrm{NaCl}$ in the fermentation medium and suggested that due to the increase of the ionic strength in the fermentation medium concluded that the high ionic strength affect the bacterium metabolic pathway.

The effect of $\mathrm{NaCl}$ it was also shown on the growth of bacteria. It appeared that the concentration of inhibitor affects the bacterial growth and as concentration increased, the final biomass concentration was lower. The results shown in Fig. $4 \mathrm{c}$ and $5 \mathrm{c}$ showed that the addition of $\mathrm{NaCl}$ and $\mathrm{NaCH}_{3} \mathrm{COOH}$ to the medium adversely affected on bacterial growth and this 
finding agreed with. Niel et al. ${ }^{[5]}$ they suggested that high salt concentration affect the bacterial growth and lead to cell lyses. Biomass concentration was enhanced from $1.1 \mathrm{gL}^{-1}$ at $\left(5 \mathrm{gL}^{-1} \mathrm{NaCl}\right)$ to $1.31 \mathrm{gL}^{-1}$ at $\left(0.0 \mathrm{gL}^{-1}\right.$ $\mathrm{NaCl}$ ). Same trend was shown for $\mathrm{NaCH}_{3} \mathrm{COOH}$ addition on bacterial growth.

The results shown in Fig. 5 (c) showed that the biomass concentration was enhanced from $1.18 \mathrm{gL}^{-1}$ at (3) $\mathrm{gL}^{-1}\left[\mathrm{NaCH}_{3} \mathrm{COO}^{-}\right]$to $1.34 \mathrm{gL}^{-1}$ at $\left(0.0 \mathrm{gL}^{-1}\right.$ $\left[\mathrm{NaCH}_{3} \mathrm{COO}^{-}\right]$.

Mechanisms of sodium chloride inhibition on $\mathbf{h}_{2}$ production: The results obtained in Fig. $4 \mathrm{a}$ and $\mathrm{b}$ showed that both $\mathrm{H}_{2}$ productivity and yield were influenced by addition of $\mathrm{NaCl}$ to fermentation medium. Zheng et al. ${ }^{[25]}$ reasoned that to the ionic strength of the medium. Das and Veziroglu ${ }^{[1]}$ they mentioned that many ions could be inhibitory or toxic to $\mathrm{H}_{2}$ producing microorganisms, depending on their concentration. A trace level of many ions is required for activation of function of many enzymes and coenzymes. Excessive amounts, however, can lead to

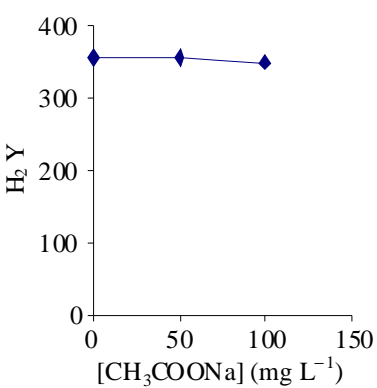

(a)

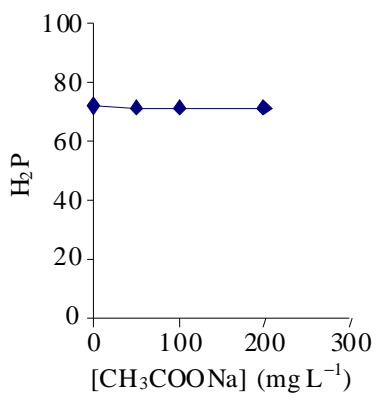

(c)

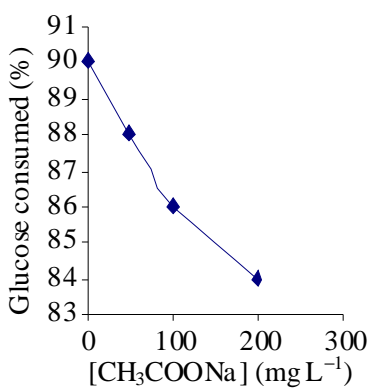

(b)

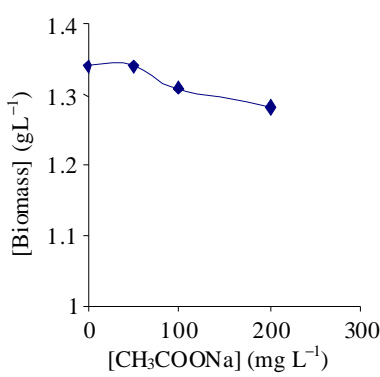

(d)
Fig. 5: Effect of [ $\left.\mathrm{NaCH}_{3} \mathrm{COO}^{-}\right]$on (a): $\mathrm{H}_{2}$ yield $\left(\mathrm{mL} \mathrm{g}^{-1}\right.$ glucose utilized); (b): $\mathrm{H}_{2} \mathrm{P}$ (Productivity $\left(\mathrm{mlL}^{-1} \mathrm{~h}^{-1}\right)$; (c): [Biomass] $\left(\mathrm{gL}^{-1}\right)$ and (d): Glucose consumption (\%). [Glucose]: $5 \mathrm{gL}^{-1}$, inoculum size $10 \%(\mathrm{v} / \mathrm{v}) \mathrm{I} \mathrm{pH}$. 7.0. Temperature $30^{\circ} \mathrm{C}$ inhibition or toxicity. This is mostly due to chemical binding of some metals to the enzymes, resulting in the disruption of enzyme structure and activities. Zheng et al. ${ }^{[25]}$. However, the inhibitory effect of $\mathrm{NaCl}$ on hydrogen production should not be related to the disruption of structure and activities of enzymes responsible for $\mathrm{H}_{2}$ production, as $\mathrm{NaCl}$ dose not bind to the enzyme. With high concentration of $\mathrm{NaCl}$, high osmolarity environments trigger rapid fluxes of cell water, thus causing a reduction in turgor and dehydration of the cytoplasm ${ }^{[26]}$.

In previous studies about the effect of $\mathrm{NaCl}$ on methanogenic microorganisms Zheng et al. ${ }^{[25]}$ stated that high osmolarity has been found to be responsible for the inhibition of $\mathrm{NaCl}$ on bacterial bioactivities. This was also likely to be the mechanism for $\mathrm{NaCl}$ inhibition of hydrogen production in the present study. Lin and Lay ${ }^{[27]}$ reported that magnesium, sodium, zinc and iron were important trace metals affecting hydrogen production by mixed culture with magnesium being the most significant. To find out the effect of sodium ions on the enzymes activity, Maris et al. ${ }^{[28]}$ they study the levels of enzymes involved in the formation of acetate and butyrate in C. acetobutylicum. They found that in the pathway to form acetate, that this bacterium produces two enzymes, which are phosphate acetyltransferase and acetate kinase, found that the activity of phosphate acetyltransferase inhibited by monovalent cation like $\mathrm{Na}^{+}$. It seems that the medium components was totally responsible of the inhibition of hydrogen production and with relation to other study weather the addition was to activate or to inhibit depend on the microorganism (s) used.

Previous investigations on sodium inhibition were mainly concentrated on undomesticated methanogenic bacteria in anaerobic digestion process and under different conditions, different bacteria (microbes) have different tolerances to sodium toxicity. Finally, $\mathrm{NaCl}$ is one of yeast extract (Nitrogen source) composition so it might be that has another inhibitory effect and reduce the quantity of produced gases. In our study the results show to the first time that $\mathrm{NaCl}$ with any concentration in fermentation medium have negative effect on hydrogen production by pure bacterium we used in this study.

Inhibition by sodium acetate: The results shown in Fig. 5a-c demonstrated that hydrogen production by C.acetobutylicum NCIMB 13357, was depending on Sodium Acetate concentration and as Sodium Acetate concentration increased the hydrogen production yield and that connected to bacterium productivity of hydrogen were decreased. As we mentioned earlier 
regarding the effect of sodium chloride, Niel et al. ${ }^{[25]}$ reasoned that inhibition of decreased hydrogen production to increase in concentration of the acetate in the fermentation medium and that affect the bacterium metabolic pathway. The effect of Sodium Acetate concentration it was also shown on the growth of bacteria. Growth was checked by final biomass concentration (bacterial dry weight). It appeared that concentration of inhibitor affect the bacterial growth and as concentration increased, the biomass concentration was decreased. Niel et al. ${ }^{[25]}$ suggested that to cell lysis. Chia et al. ${ }^{[29]}$ reported the summary of previously reported that Sodium Acetate salt effects on yeast growth. They reported that elevated levels of inorganic electrolytes in the liquid growth medium have been found to influence several parameters of yeast activity. (i) Cell growth and multiplication: (a) The number of viable yeast cells per unit volume of liquid growth medium decreases as salt content increases, (b) The biomass of the culture (i.e., the total weight of yeast cells per unit volume of liquid growth medium) decreases as salt content increases and (c) The length of the lag phase (i.e., the incubation period between inoculation of the culture and detectable initiation of cell growth) lengthens as salt concentration increases. (ii) Utilization of the primary carbon and energy source is reduced. (iii) Change in concentration of metabolic products: (a) There is a decrease in the production of ethanol as salt content increases and (b) There is an increase in the concentration of other fermentation products (such as glycerol, acetaldehyde) as salt content increases. Biggins et al. ${ }^{[30]}$ reported that an increase in the concentration of acetate within the cell to partially inhibit acetate kinase activity, resulting in elevated concentrations of acetyl phosphate in C. pasteurianum. They found also that Acetyl phosphate acted as a product inhibitor of pyruvate phosphoroclastic activity and apparently resulted in a slowdown of general metabolism. Another study was conducted by Robert Bechtle $^{[31]}$ reported that sodium acetate was shown to have a potentiating effect on some proteases in hydrolysis of milk proteins at acid $\mathrm{pH}$ values and that effect was minimal in neutral $\mathrm{pH}$ media and there was an inhibition of the protease activity at alkaline $\mathrm{pH}$ values under some conditions. This, as well as observations reported here, would indicate as they reported in their study that, acetate ions may have a stimulatory or inhibitory action on an enzyme system, depending on the $\mathrm{pH}$, the substrate and the enzyme involved. Inhibition of growth by acetate and other weak organic acids is quite common, but the level of tolerance varies tremendously among species. The undissociated form of these compounds can function as uncoupling agents ${ }^{[32]}$. However, Niel et al. ${ }^{[25]}$ reported that, the ionic strength of sodium acetate was responsible for the inhibition of the hydrogen production by $C$. saccharolyticus and Donnison et al. ${ }^{[33]}$ observed that lysis in exponentially growing cultures of this organism after addition of $20 \mathrm{mM}$ sodium acetate. Similar phenomena have already been described for, C. thermoaceticum ${ }^{[34]}$ and Bacillus subtilis ${ }^{[35]}$. Wang and Wang ${ }^{[34]}$ reported that $C$. thermoaceticum release of autolysins upon addition of high salt concentrations. Kemper et $a l .{ }^{[36]}$ reported that inactive autolysins are distributed in the relatively acidic cell wall of grampositive bacteria during exponential growth. Suggested that it is thought that autolysins become activated once the $\mathrm{pH}$ of the cell wall is neutralized. Results obtained in this study imply a similar scenario in C. saccharolyticus, which possesses also a grampositive-type cell wall. Our results shows to the first time that sodium with any concentration in fermentation medium has negative effect on hydrogen production by bacterium we used in this work.

Finally the final $\mathrm{H}_{2}$ yield obtained by using the new medium was $340 \mathrm{~mL} \mathrm{~g}^{-1}$ glucose supplied $(2.72 \mathrm{~mol}$ $\mathrm{H}_{2} \mathrm{moL}^{-1}$ glucose supplied): (According to Wooshin et al. ${ }^{[37]}$ each $125 \mathrm{~mL}$ of $\mathrm{H}_{2} \approx 1$ mole $\mathrm{H}_{2}$ ) and that was higher than reported value in the literature for mesophilic species of clostridia, as reported by ${ }^{[38]}$.

\section{CONCLUSION}

We aimed in this study to improve RCM medium to be used for hydrogen production by Cacetobutylicum NCIMB13357. Obtained results show that the medium should have a proper nitrogen source (Yeast Extract). Regarding the $\mathrm{C} / \mathrm{N}$ ratio we found at 70 , the production was enhanced about $14 \%$, so proper $\mathrm{C} / \mathrm{N}$ ratio also enhance the bacterial productivity of hydrogen suggested that nitrogen should be supplied in a optimum amount, otherwise the bacterial productivity of hydrogen will be affected inversely. In RCM medium, we found that both $\mathrm{NaCl}$ and Sodium Acetate were inhibitor to the bacterium we used in this study, removing those both inhibitor from the medium was found to enhance the hydrogen production by $12 \%$. Finally the medium we formulated have Yeast Extract as preferable nitrogen source and this source also have $2.5 \%$ of $\mathrm{NaCl}$, so it might that the maximum yield we cannot reached due to the presence of this inhibitor.

\section{REFERENCES}

1. Das, D. and T.N. Veziroglu, 2001. Hydrogen production by biological processes: A survey of literature. Int. J. Hydrogen Energ., 26: 13-28. DOI: 10.1016/S0360-3199(00)00058-6 
2. Stanbury, P.F., A. Whitaker and S.J. Hall, 1995. Principles of Fermentation Technology. 2nd Edn., Pergamon, Singapore, ISBN: 0750645016 , pp: 101-102.

3. Lin, C.Y. and R.C. Chang, 1999. Hydrogen production during the anaerobic acidogenic conversion of glucose. J. Chem. Technol. Biotechnol., 74: 498-500.

http://www3.interscience.wiley.com/journal/62000 242/abstract?CRETRY $=1 \&$ SRETRY $=0$

4. Santosh, Y., T.R. Sreekrishnan, S. Kohli and V. Rana, 2004. Enhancement of biogas production from solid substrates using different techniques-a review. Bioresour. Technol., 95: 1-10. http://www.cheric.org/research/tech/periodicals/vie w.php?seq $=461937$

5. Niel, E.W.J., P.A.M. Claassen and A.J.M. Stam, 2003. Substrate and product inhibition of hydrogen production by the extreme thermophilic, Caldicellulosiruptor saccharolyticus. Biotechnol. Bioeng., 81: 255-262. DOI: 10.1002/bit.10463

6. Morimoto, M., M. Atsuko, A.A.Y. Atif, M.A. Ngan, A. Fakhrul-Razi, S.E. Iyuke and A.M. Bakir, 2004. Biological production of hydrogen from glucose by natural anaerobic microflora. Int. J. Hydrogen Energ., 29: 709-713.

DOI: 10.1016/J.Ijhydene.2003.09.009

7. Miller, G.L., 1959. Use of Dinitrosalicyclic acid reagent for determination of reducing sugar. Anal. Chem., 31: 426-429. DOI: 10.1021/ac60147a030

8. Greenberg, A.E., L.S. Clesceri and A.D. Eaton, 1992. Standard Methods for the Examination of Water and Wastewater. 18th Edn., American Public Health Association, Washington DC.,USA., ISBN: 08-755-32071.

9. Lay, J.J., 2001. Biohydrogen generation by mesophilic anaerobic fermentation of microcrystalline cellulose. Biotechnol. Bioeng., 74: 280-287. DOI: 10.1002/bit.1118

10. Mongi, F., C. Edward, H. William, G. Gwang-Hoon and A. Almadidy, 2005. Influence of culture parameters on biological hydrogen production by Clostridium saccharoperbutylacetonicum ATCC 27021. World J. Microbiol. Biotechnol., 120: 402-409. DOI: 10.1016/J.Jbiotec.2005.05.017

11. Chen, C.C., C.Y. Lin and M.C. Lin, 2002. Acidbase enrichment enhancement on anaerobic hydrogen production process. Applied Microbiol. Biotechnol., 57: 224-228. DOI: 10.1007/s002530100814

12. Logan, B.E., S.E. Oh, I.S. Kim and S. Van Ginkel, 2002. Biological hydrogen production measured in batch anaerobic respirometers. Environ. Sci. Technol., 36: 2530-2535.

http://www.engr.psu.edu/ce/enve/publications/2002 -Logan-etal-H2.pdf
13. Lin, C.Y. and R.C. Chang, 2004. Fermentative hydrogen production at ambient temperature. Int. J. Hydrogen Energ., 29: 715-720. DOI: 10.1016/J.Ijhydene.2003.09.002

14. Oh, Y.K., E.H. Seol, J.R. Kim and S. Park, 2003. Fermentative biohydrogen production by a new chemoheterotrophic bacterium citrobacter sp. Y19. Int. J. Hydrogen Energ., 28: 1353-1359. DOI: 10.1016/S0360-3199(03)00024-7

15. Zhang, T., H. Liu and H.H.P. Fang, 2003. Biohydrogen production from starch wastewater under thermophilic condition. J. Environ. Manage., 69: 149-156. DOI: 10.1016/S0301-4797(03)00141-5

16. Ueno, Y., S. Haruta, M. Ishii and Y. Igarashi, 2001. Microbial community in anaerobic hydrogen-producing microflora enriched from sludge compost. Applied Microbiol. Biotechnol., 57: 555-562. DOI: 10.1007/s002530100806

17. Large, P.J., 1986. Degradation of organic nitrogen compounds by yeasts. Yeast, 2: 1-34. http://www3.interscience.wiley.com/journal/10758 2575/abstract?CRETRY $=1 \&$ SRETRY $=0$

18. Lin, C.Y. and C.H. Lay, 2004. Carbon/nitrogenratio effect on fermentative hydrogen production by mixed microflora. Int. J. Hydrogen Energ., 29: 41-45. DOI: 10.1016/S0360-3199(03)00083-1

19. Van Ginkel, S.W., J.J. Lay and S. Sung, 2001. Biohydrogen Production as a function of $\mathrm{pH}$ and substrate concentration. Environ. Sci. Technol., 35: 4719-4725.

http://cat.inist.fr/?aModele $=$ afficheN\&cpsidt $=1339$ 0673

20. Bisaillon, A., J. Turcotte and. P.C. Hallenbeck, 2005. The Effect of nutrient limitation on hydrogen production by Escherchia coli. Proceedings of the International Hydrogen Energy Congress and Exhibition, July 13-15, Istanbul, Turkey, pp: 1-6. http://www.unido-

ichet.org/ihec2005/files/manuscripts/Hallenbeck\% 20P.C.-Canada.pdf

21. Tanisho, S., M. Kuromoto and N. Kadokura, 1998. Effect of $\mathrm{CO} 2$ removal on hydrogen production by fermentation. Int. J. Hydrogen Energ., 23: 559-563. DOI: 10.1016/S0360-3199(97)00117-1

22. Aiyer, D.P.V., 2004. Effect of C:N ratio on alpha amylase production by Bacillus licheniformis SPT 27. Afr. J. Biotechnol., 3: 519-522. http://www.bioline.org.br/request?jb04104

23. Gottschal, J.C. and J.G. Morris, 1981. Non production of acetone and butanol by Clostridium acetobutylicum during glucose and ammoniumlimitation in continuous culture. Biotechnol. Lett., 3: 525-530. DOI: 10.1007/BF00147566 
24. Yokoi, H., A. Saitsu, H. Uchida, J. Hirose, S. Hayashi and Y. Takasaki, 2001. Microbial hydrogen production from sweet potato starch residue. J. Biosci. Bioeng., 91: 58-63. DOI: 10.1016/S13891723(01)80112-2

25. Zheng, X.J., Y.M. Zheng and H.Q. Yu, 2005. Influence of $\mathrm{NaCl}$ on hydrogen production from glucose by anaerobic cultures. Environ. Technol., 26: 1073-1080.

http://cat.inist.fr/?aModele=afficheN\&cpsidt=1729 6513

26. Ahring, B.K. and P. Westermann, 1983. Toxicity of heavy metals to thermophilic anaerobic bacteria digestion. Applied Microbial Biotechnol., 17: 365-370. DOI: $10.1007 / \mathrm{BF} 00499505$

27. Lin, C.Y. and C.H. Lay, 2005. A nutrient formulation for fermentative hydrogen production using anaerobic sewage sludge microflora. Int. J. Hydrogen Energ., 30: 285-292. DOI: 10.1016/j.ijhydene.2004.03.002

28. Maris, G., N. Hartmanis and G. Sten, 1984. Intermediary metabolism in Clostridium acetobutylicum: Levels of enzymes involved in the formation of acetate and butyrate. Applied Environ. Microbiol., 1277-1283. http://aem.asm.org/cgi/content/abstract/47/6/1277

29. Chia-Jenn, W., D. Robert, D. Tanner, W. George and M. Malaney, 1982. Effect of sodium chloride on bakers yeast growing in gelatin. Applied Environ. Microbiol., 757-763. http://aem.asm.org/cgi/content/abstract/43/4/757

30. Biggins, D.R. and M. J. Dilworth, 1968. Control of pyruvate phosphoroclastic activity in extracts of Clostridium pasteurianum by ADP and acetyl phosphate. Biochem. Biophys. Acta,156: 285-296. http://www.ncbi.nlm.nih.gov/pubmed/4230545
31. Robert, M. Bechtle, 1969. Effect of sodium acetate on protease activity. J. Dairy Sci., 52: 1733-1737. http://jds.fass.org/cgi/reprint/52/11/1733.pdf

32. Booth, I.R., 1985. Regulation of cytoplasmic $\mathrm{pH}$ in bacteria. Microbiol. Rev., 49: 359-378. http://mmbr.asm.org/cgi/content/citation/49/4/359.

33. Donnison, A.M., C.M. Brockelsby, H.W. Morgan and R.M. Daniel, 1989. The degradation of lignocellulosics by extremely thermophilic microorganisms. Biotechnol. Bioeng., 33: 14951499. http://www.ncbi.nlm.nih.gov/pubmed/18587891

34. Wang, G. and D. Wang, 1984. Elucidation of growth inhibition and acetic acid production by Clostridium thermoaceticum. Applied Environ. Microbiol., 47: 294-298. http://aem.asm.org/cgi/content/abstract/47/2/294

35. Joliffe, L.K., R.J. Doyle and U.N. Streips, 1981. The energized membrane and cellular autolysis in Bacillus subtilis. Cell, 25: 753-763. http://www.ncbi.nlm.nih.gov/pubmed/6793239

36. Kemper, M.A., M.M. Urrutia, T.J. Beveridge, A.L. Koch and R.J. Doyle, 1993. Proton motive force regulate cell wall-associated enzymes of Bacillus subtilis. Cell, 25: 753-763.

37. Wooshin, P., H.H. Seung, O.H. Sang-Eun, B.E. Logan and I.S. Kim, 2005. Removal of headspace $\mathrm{CO}_{2}$ increases biological hydrogen production. Environ. Sci. Technol., 39: 4416-4420. http://www.ncbi.nlm.nih.gov/pubmed/16047775

38. Collect, C., N. Adler, J.P. Schwitzguebel and P. Peringer, 2004. Hydrogen production by Clostridium thermolacticum during continuous fermentation of lactose. Int. J. Hydrogen Energ., 29: 1479-1485.

DOI: 10.1016/J.Ijhydene.2004.02.009 